\title{
Yield performance of eight snap bean genotypes grown under an organic management system in the tropics ${ }^{1,2}$
}

\author{
Bryan Brunner ${ }^{3}$, Kevin Brady ${ }^{4}$ Luisa Flores ${ }^{5}$ \\ and James $S$. Beaver ${ }^{6}$
}

J. Agric. Univ. P.R. 98(1):15-20 (2014)

\begin{abstract}
Eight snap bean (Phaseolus vulgaris L.) cultivars and lines were grown under an organic management system in 2011 and 2012 in Lajas, Puerto Rico. Bean genotypes used in the trial were the commercial cultivars 'Contender', 'Festina', 'Fresh Pick', 'Jade', 'Nash' and 'Provider', and two experimental breeding lines PR1018-1 and PR1018-5. In 2011, 'Provider' and PR1018-5 had the highest yields, with 11.2 and 11.1 tha, respectively, but these were not significantly different from the yields of 'Contender', 'Festina', PR1018-1 or 'Nash'. 'Jade' had the lowest yield, with 6.5 tha. In 2012, the highest yielding cultivar was 'Festina', with $14.6 \mathrm{t} / \mathrm{ha}$, which was not significantly different from 'Nash' (13.8 t/ha), PR1018-5 (12.6 t/ha) or 'Jade' (12.5 tha). 'Contender' (9 tha), 'Provider' ( 8.4 t/ha) and 'Fresh Pick' ( 8.4 tha) had the lowest yields. This study has shown that snap beans can be successfully grown in Puerto Rico under an organic management system, with yields similar or superior to conventionally produced snap beans.
\end{abstract}

Key words: snap bean, Phaseolus vulgaris, organic production, variety trial, tropics

\section{RESUMEN}

Rendimiento de ocho cultivares de habichuela tierna cultivados bajo un sistema de manejo orgánico en el trópico

Se llevó a cabo un ensayo con ocho cultivares y líneas de habichuela tierna (Phaseolus vulgaris L.) bajo un sistema de manejo orgánico en 2011 y 2012 en Lajas, Puerto Rico. Los genotipos que se usaron en el ensayo

${ }^{1}$ Manuscript submitted to Editorial Board 9 September 2013.

${ }^{2}$ This material is based on work supported by the Natural Resources Conservation Service, U.S. Department of Agriculture, under number NRCS 69-F352-09-0.

${ }^{3}$ Corresponding author. Researcher, Agricultural Experiment Station, HC-02 Box 11656, Lajas, PR 00667. Email: bryan.brunner1@upr.edu

${ }^{4}$ Former graduate student, Department of Horticulture, University of Puerto Rico, Mayagüez Campus.

${ }^{5}$ Research Associate, Agricultural Experiment Station, Lajas, PR

${ }^{6}$ Professor, Department of Crops and Agroenvironmental Sciences, University of Puerto Rico, Mayagüez Campus. 
fueron los cultivares comerciales 'Contender', 'Festina', 'Fresh Pick', 'Jade', 'Nash' y 'Provider', y dos líneas experimentales PR1018-1 y PR1018-5. En el 2011, 'Provider' y PR1018-5 tuvieron los rendimientos más altos, con 11.2 y 11.1 tha, respectivamente, pero no fueron significativamente diferentes a los rendimientos de 'Contender', 'Festina', PR1018-1 o 'Nash'. 'Jade' tuvo el rendimiento más bajo, con 6.5 t/ha. En el 2012 , el cultivar de mayor rendimiento fue 'Festina', con 14.6 tha, lo que no fue significativamente diferente a los rendimientos de 'Nash' (13.8 t/ha), PR1018-5 (12.6 t/ha) o 'Jade' (12.5 t/ha). 'Contender' (9 t/ha), 'Provider' ( 8.4 t/ha) y 'Fresh Pick' ( 8.4 tha) tuvieron los rendimientos más bajos. Este estudio ha demostrado que las habichuelas tiernas se pueden cultivar exitosamente bajo un sistema de manejo orgánico en Puerto Rico, obteniendo rendimientos similares o superiores a los de habichuela tierna producida de manera convencional.

Palabras clave: habichuela tierna, Phaseolus vulgaris, producción orgánica, ensayo de variedades, trópico

\section{INTRODUCTION}

Organic agriculture is expanding rapidly worldwide, with 1.8 million certified producers farming 32.5 million hectares in 2011 (FiBL \& IFOAM, 2013). This growth is being driven largely by consumer demand for pesticide free food which is produced using environmentally friendly methods. In order to meet increased interest and demand for locally produced organic foods, growers in Puerto Rico need information on cultivars and production practices appropriate for tropical growing conditions.

Snap bean (Phaseolus vulgaris L.) is a relatively minor crop in Puerto Rico, with a modest production of $42 \mathrm{t}$ and a value of $\$ 52,000$ in 2010 (Departament of Agriculture of Puerto Rico, 2012). However, it is an agricultural product with high potential as a cash crop for smallscale farmers, due to its short crop cycle, high production, and desirable nutrient profile for consumers (David et al., 2000). Furthermore, a total of 2,439 $\mathrm{t}$ of fresh, frozen, and canned snap beans are imported annually (U.S. Census Bureau, 2012), most or all of which could be produced locally, thus decreasing its carbon footprint while enhancing freshness and local food security.

Silbernagel et al. (1991) noted that snap bean production in the tropics requires the identification of farming systems and cultural practices that are less dependent on agrochemicals. Sustainable organic vegetable production can be achieved by sound crop management strategies and the use of cultivars adapted to local conditions (Palada and Davis, 2001). Organic producers need to find cultivars adapted to both the system specific needs of organic agriculture and the location of intended cultivation. Knowledge of superior performing cultivars can increase farm stability and profitability by avoiding the expense of investing in poorly adapted cultivars (Colley and Myers, 2007). 
The objective of this study was to evaluate the adaptability and performance of eight snap bean cultivars and lines under an organic management system in a tropical environment at Lajas, Puerto Rico.

\section{MATERIALS AND METHODS}

The variety trial was conducted at the Lajas Substation of the University of Puerto Rico Agricultural Experiment Station in southwestern Puerto Rico (lat. $18^{\circ} 01^{\prime} \mathrm{N}$, long. $67^{\circ} 04^{\prime} \mathrm{W}$, elevation $27 \mathrm{~m}$ ). The soil series is Fraternidad clay that is very deep, moderately well drained, very slowly permeable, and weathered from volcanic rock and limestone (National Cooperative Soil Survey USA, 2006). Soil tests on site revealed high levels of potassium, magnesium, calcium, and copper, with low levels of phosphorous and zinc. Soil pH was 8.2.

Eight snap bean cultivars and lines were planted 29 March 2011 and 13 January 2012. Criteria for cultivar selection included high yield, heat tolerance, virus resistance, and eating quality. Bean cultivars used in the trial were the commercial cultivars 'Contender', 'Festina', 'Fresh Pick', 'Jade', 'Nash', 'Provider', and two experimental breeding lines, PR1018-1 and PR1018-5. Lines PR1018-1 and PR10185 were developed at the University of Puerto Rico and have resistance to bean common mosaic virus (BCMV) and bean golden yellow mosaic virus (BGYMV). They were the highest yielding lines in a 2009 organic bean variety trial conducted in Lajas (J. Halbrendt, unpublished).

Prior to planting, we incorporated composted cow manure at a rate of 34 t/ha and BioFlora Dry Crumbles 6-6-5 (Global Organics, Goodyear, Arizona $)^{7}$ to supply $56 \mathrm{~kg} / \mathrm{ha} \mathrm{N}$. The experiment was established using a randomized complete block design with six replications. Experimental units were $2 \mathrm{~m}$ rows planted with 30 seeds each at a planting distance of approximately $6 \mathrm{~cm}$. Rows were spaced $0.76 \mathrm{~m}$ apart. Drip irrigation was supplied as needed. Plants were mulched with $15 \mathrm{~cm}$ of cut grass to control weeds and conserve soil moisture.

A bi-weekly spray program was used to control insect pests, primarily the bean leaf beetle (Cerotoma ruficornis), white fly (Bemisia tabaci) and several aphid species, which are virus vectors. Spray products, which were alternated, included Trilogy (Certis USA, Columbia, Maryland), Garlic Barrier (Garlic Research Labs, Glendale, California), Surround WP Crop Protectant (Tessenderlo Kerley, Phoenix, Arizona) and

\footnotetext{
${ }^{7}$ Company or trade names in this publication are used only to provide specific information. Mention of a company or trade name does not constitute a warranty of equipment or materials by the Agricultural Experiment Station of the University of Puerto Rico, nor is this mention a statement of preference over other equipment or materials.
} 
Pyganic EC 5.0 (MGK Company, Minneapolis, Minnesota). All products were OMRI (Organic Materials Research Institute) approved. Plants with virus symptoms were uprooted and eliminated from the field to reduce disease transmission. Roguing of plants with virus symptoms was discontinued at flowering.

Pods were harvested at about the diameter of a pencil (ca. 6-7 mm), before the seeds became evident; multiple harvests were necessary to completely gather the ripe pods. Informal quality evaluations on the raw pods were conducted by $\mathrm{K}$. Brady in 2011 to assess taste, color, texture and shape.

Pod yield and data for number of plants with virus symptoms were analyzed for statistical significance using Statistix 10.0 analytical software (Tallahassee, Florida).

\section{RESULTS AND DISCUSSION}

Disease and pest incidence was low in both years. In 2011, the incidence of virus symptoms was not significantly different among cultivars (data not shown), and ranged from 1.3 plants per plot for 'Provider' to 0.2 plants per plot for 'Festina', 'Fresh Pick', 'Jade', 'Nash' and PR1018-5. In 2012, plants with virus symptoms were almost nonexistent. Web blight, caused by Rhizoctonia solani, was observed in 2011, but not in 2012 , and appeared to be randomly distributed throughout the plots, affecting only about 15 plants in the entire experiment. In 2011, high rainfall during the harvest period caused some fungal infection, mostly on pods which had soil contact, making some pods unmarketable and reducing yield.

In 2011, plants were harvested twice, during the period of 13 to 16 May and on 23 May (43 to 55 days after planting). 'Provider' and PR1018-5 had the highest yields, with 11.2 and $11.1 \mathrm{t} / \mathrm{ha}$, respectively, but these yields were not significantly different from the yields of 'Contender', 'Festina', PR1018-1 or 'Nash' (Table 1). 'Jade' had the lowest yield, with $6.5 \mathrm{t} / \mathrm{ha}$.

In 2012 there were three harvests, on 1, 5 and 27 March (48 to 74 days after planting). Overall, pod yields were higher in 2012. The highest yielding variety was 'Festina', with $14.6 \mathrm{t} / \mathrm{ha}$, which was not significantly different from 'Nash' (13.8 t/ha), PR1018-5 (12.6 t/ha) or 'Jade' (12.5 t/ha). 'Contender' ( 9 t/ha), 'Provider' (8.4 t/ha) and 'Fresh Pick' (8.4 t/ha) had the lowest yields (Table 1 ).

In the analysis of variance combined over years, the cultivar $\mathrm{x}$ year interaction was significant $(\mathrm{P}<0.001)$. 'Contender', 'Fresh Pick', PR1018-1 and PR1018-5 had greater yield stability from year to year, and did not show a significant change in yield, whereas 'Festina' and 'Jade' had lower yield stability in this environment. 
TABLE 1.-Fresh pod weight $(t / h a)$ of eight snap bean genotypes grown organically at the Lajas Agricultural Experiment Station in 2011 and 2012.

\begin{tabular}{lcc}
\hline & \multicolumn{2}{c}{${\text { Yield }(\mathrm{t} / \mathrm{ha})^{1}}^{1}$} \\
\cline { 2 - 3 } Genotype & 2011 & 2012 \\
\hline Festina & $10.9 \mathrm{ab}$ & $14.6 \mathrm{a}$ \\
Nash & $10.2 \mathrm{ab}$ & $13.8 \mathrm{ab}$ \\
PR1018-5 & $11.1 \mathrm{a}$ & $12.6 \mathrm{ab}$ \\
PR1018-1 & $10.5 \mathrm{ab}$ & $11.8 \mathrm{~b}$ \\
Contender & $11.0 \mathrm{ab}$ & $9.0 \mathrm{c}$ \\
Provider & $11.2 \mathrm{a}$ & $8.4 \mathrm{c}$ \\
Jade & $6.5 \mathrm{c}$ & $12.5 \mathrm{ab}$ \\
Fresh Pick & $8.0 \mathrm{bc}$ & $8.4 \mathrm{c}$ \\
Mean & 9.9 & 11.4 \\
\hline
\end{tabular}

${ }^{1}$ Within columns, means followed by the same letter are not significantly different according to the LSD test $(\mathrm{P}<0.05)$.

Our yields of organic snap beans compare very favorably with those of conventional snap bean production. In a conventional snap bean variety trial in Egypt, yields of between 8.2 and 11.7 t/ha were reported (Abdel-Mawgoud et al., 2005). In Alabama, USA, snap bean yields with conventional fertilizer ranged from 3.8 to $11.1 \mathrm{t} / \mathrm{ha}$; when the crop was fertilized with broiler litter, a production of between 2.9 and $14.6 \mathrm{t} / \mathrm{ha}$ was observed (Brown et al., 1993). According to FAOSTAT (FAO, 2013), the mean snap bean yield in the USA is $8.2 \mathrm{t} / \mathrm{ha}$. It should be noted that much of the commercial snap bean production in the USA is mechanically harvested in a single operation, as opposed to hand harvesting in several passes, as was used in our study. The harvest method could have an effect on the observed yields.

'Festina' was rated the highest in informal quality evaluations on the raw pods. It had uniformly straight, dark green pods with a juicy, tender, dense texture. 'Nash' was similar in raw eating quality, but not as juicy. 'Provider' and 'Contender' were similar to each other, with a light green pod color that was less visually attractive, a mix of curved and straight pods, and a less juicy and less dense texture. PR1018-1 and PR1018-5 were similar to each other, light green in color, slightly curved, with a less juicy and less dense texture, but appeared to have a long shelf life. 'Jade' and 'Fresh Pick' were both attractive in appearance, but 'Fresh Pick' pods were somewhat tough and both were low yielders.

\section{CONCLUSION}

This study has shown that snap beans can be successfully grown in Puerto Rico under an organic management system, producing yields 
similar or superior to conventionally grown snap beans. The cultivars differed in their yield performance and quality. In terms of yield and quality, 'Festina' and 'Nash' are outstanding cultivars for fresh market organic production. Lines PR1018-1 and PR1018-5 also had high yields, and exhibited greater yield stability under the growing conditions at Lajas. They may also have performed better in relation to the other cultivars if virus pressure had been greater.

\section{LITERATURE CITED}

Abdel-Mawgoud, A. M. R., M. El-Desuki, S. R. Salman and S. D. Abou-Hussein, 2005. Performance of some snap bean varieties as affected by different levels of mineral fertilizers. J. Agron. 4(3):242-247.

Brown, J. E., C. H. Gilliam, R. L. Shumack and D. W. Porch, 1993. Commercial snap bean response to fertilization with broiler litter. HortScience 28(1):29-31.

Colley, M. and J. Myers, 2007. On-farm variety trials: A guide for organic vegetable, herb, and flower producers. Organic Seed Alliance. http://www.seedalliance.org/uploads/publications/OVT_Guide.pdf (verified 31 July 2013)

David, S., R. Kirkby and S. Kasozi, 2000. Assessing the impact of bush bean varieties on poverty reduction in sub-Saharan Africa: Evidence from Uganda. Network on bean research in Africa. Occasional Publications Series, No. 31, CIAT, Kampala, Uganda.

Department of Agriculture of Puerto Rico, 2012. Ingreso Bruto Agrícola 2010-2011. Oficina de Estadísticas Agrícolas. http://www2.pr.gov/agencias/Agricultura/PrimerasEmpresasAgricolas/Documents/Ornamentales/IngresoBrutoAgrícola 2010-2011.pdf (verified 31 July 2013)

FiBL \& IFOAM, 2013. The world of organic agriculture: Statistics and emerging trends 2013. H. von Willer, J. Lernoud and L. Kilcher (eds.). FiBL \& IFOAM.

Food and Agriculture Organization (FAO), 2013. FAOSTAT. Statistics Division of the Food and Agriculture Organization. http:/faostat.fao.org (verified 31 July 2013)

National Cooperative Soil Survey USA, 2006. Fraternidad series. https://soilseries. sc.egov.usda.gov/OSD_Docs/F/FRATERNIDAD.html (verified 31 July 2013)

Palada, M. and A. Davis, 2001. Yield performance of tomato cultivars grown under organic management system. Proceedings of the Caribbean Food Crops Society 37:154-160.

Silbernagel, M., W. Jassen, J. H. C. Davis and G. Montes de Oca, 1991. Snap bean production in the tropics: Implications for genetic improvement. p. 835-862. In: Common beans: Research for crop improvement. A. van Schoonhoven and O. Yoysest (eds.). CAB International in association with CIAT, Cali, Colombia.

US Census Bureau, 2012. U.S. trade with Puerto Rico and U.S. possessions. http://www. census.gov/prod/2013pubs/FT8952012annual.pdf (verified 31 July 2013). 